\title{
Using effect size in evaluating academic engagement and motivation in a private business school
}

\author{
Jarno Einolander ${ }^{1}$, Evangelos Markopoulos², Jussi Kantola ${ }^{3,4}$, Hannu Vanharanta ${ }^{1,4}$ \\ ${ }^{1}$ University of Vaasa, Wolffintie 34, 65200 Vaasa, Finland \\ ${ }^{2}$ HULT International Business School, 35 Commercial Road, Whitechapel, E1 1LD London \\ United Kingdom. \\ ${ }^{3}$ University of Turku, Department of Mechanical Engineering, 20014 Turku, Finland \\ ${ }^{4}$ Poznan University of Technology, Plac Marii Skłodowskiej-Curie 5, 60-965 Poznań, Po- \\ land \\ jarno.einolander@gmail.com, evangelos.markopoulos@faculty.hult.edu, jusil- \\ akan@gmail.com, hannu@vanharanta.fi
}

\begin{abstract}
This research analyses student engagement and motivation data gathered from a UK-based private business university and multiple European public universities. The data was obtained using an Internet-based generic expert system called Evolute. In this research, the self-evaluation results from 40 undergraduate business school students were subjected to comparison analysis using an effect size described by Cohen's d-values. Using the effect size in the analysis helps to easily identify the areas or the specific items where the benchmarked university is doing well compared to others, as well as to find out the areas or items that could be subjected for improvement. According to the results, the benchmarked institution scored higher mean values in 95 percent of statements than all the other cases conducted with the instrument at public universities.
\end{abstract}

Keywords: Student Engagement $\cdot$ Commitment $\cdot$ Expert System $\cdot$ Private Academic Institution

\section{Introduction/ Student Engagement and Retention}

Student engagement describes the time and effort students dedicate to activities that are related to the desired outcomes of the educational institutions, and on what these institutions do to encourage students to participate in these activities [1]. Student engagement is often considered the best predictor of student learning and development $[2 ; 3]$. According to Harper and Quaye [4], engagement is not just involvement or participation; it also necessitates feelings and sense-making as well as being active. The majority of the research uses the definition of student engagement proposed by Astin, who defined student engagement as "the amount of physical and psychological energy that the student devotes to the academic experience" [5]. Student engagement is also defined as "the time and effort that students devote to educational activities, which are linked to desired outcomes" [6]. According to Kuh [1], a conclusion from 
most of the student engagement studies is that higher levels of engagement relate to higher academic performance, lower attrition, and higher retention rates.

Motivation is a complicated and complex issue that combines several specific behavioral factors such as needs, desires, efforts, and expectations. Students can be motivated but not actively engaged in a task. Thus motivation is necessary, but not enough for engagement [7]. Furthermore, motivation is a personal condition that encourages individuals to plan, implement, and desire certain activities to achieve a previously set goal. Motivation involves making the inputs that are necessary for changing the work, attitudes, and behavior [8].

Research suggests that an understanding of student engagement can help educators to prevent harmful outcomes and promote positive ones for at-risk students [10]. Therefore, it is important to measure and benchmark these factors affecting the student's engagement, so that the development activities and efforts can be directed of most beneficial areas. The objective of this paper was to analyze student engagement and motivation in a group of undergraduate students attending a private business school, in comparison to students attending public universities.

\section{Student Engagement in Private Academic Institutions}

Tinto [11] argues that students are more likely to stay and graduate when the institute, (1) expects them to succeed, (2) provides academic, social and personal support, (3) gives feedback regularly on their performance, (4) regards them as significant members of the institution (e.g., frequent and high-quality interaction with the academics, the staff, and other students), and most importantly (5) fosters learning. However, there might be differences in the priorities between public and private institutes of higher education. Private institutions have different operation principles, management practices, strategies and standards from the public (government) institutions. In private institutions, the students pay higher tuition fees and have expectations that could differ from what students expect in state institutions primarily in operations, support, administration management, infrastructure, and to an extent in the teaching quality, career development, student life, activities, etc. Many private academic institutions can be considered highly multicultural therefore the student engagement and commitment need to be approached from a cultural dimension as well, in both studying and learning. This cultural diversification extends also to the financial background of the students, where many might have secured professional careers while others might enter directly into their family business. Such students expect teaching and learning to be more practical, interactive, enjoyable, and less researchdriven, more case driven and hands-on. This, on the other hand, can be a challenge for the academics who follow traditional academic teaching and research practices not quite aligned with the student's expectations and interests. Such cases, and not only, impact heavily the degree of student engagement and commitment and become quite significant issues and concerns for the development of the strategic management and leadership on the institution's operations. 


\section{Research Instrument}

The research instrument used in this case study utilizes a generic, Internet-based application environment called Evolute. The Evolute system contains several selfassessment applications for various management related objects. The expert systembased application utilizes Fuzzy Logic in its generic analyses $[12 ; 13 ; 14]$. The instruments are ontology-based, and they are used to acquire perception and collective understanding of different organizational resources.

The instrument used in this study is based on well-known models of student persistence and retention. The main models used in the creation of the framework for the ontology and the statements for the instrument application was Tinto's Student Integration Model [15; 16] and Bean's Student Attrition Model [17; 18]. The instrument was developed using ontological modeling. Ontologies are formal representations of different concepts within a domain and their relationships. They are used to reason the properties of a domain and may be used to define the domain. Gruber [19] defined an ontology as a "formal, explicit specification of a shared conceptualization". An ontology provides a shared vocabulary that can be used to model a domain that is, the type of objects and/or concepts that exist, and their properties and relations [20]. In the research instrument, the ontology consists of a classification of qualitative knowledge related to factors affecting students' engagement and motivation toward their institute of higher education and studies. The instrument contains 147 unique statements describing the features $(n=19)$ from multiple viewpoints. Table 1 present's example of features of the ontology-based application.

Table 1. Examples of Helix Academic features

\begin{tabular}{|c|c|c|}
\hline Area & Feature & Description \\
\hline & & The extent that/how the students: \\
\hline \multirow[t]{2}{*}{ Motivation } & $\begin{array}{l}\text { Goal commitment } \\
\text { (personal goals) }\end{array}$ & $\begin{array}{l}\text { are committed to the goal of obtaining a degree } \\
\text { and take responsibility for their studies. }\end{array}$ \\
\hline & $\begin{array}{l}\text { Social integration } \\
\text { (relatedness) }\end{array}$ & $\begin{array}{l}\text { assess how participation and integration to a } \\
\text { social group relates to their studies. }\end{array}$ \\
\hline \multirow[t]{2}{*}{$\begin{array}{l}\text { Learning } \\
\text { environment }\end{array}$} & $\begin{array}{l}\text { Responsive envi- } \\
\text { ronment }\end{array}$ & $\begin{array}{l}\text { feel the study environment is responsive to pro- } \\
\text { moting effective learning. }\end{array}$ \\
\hline & Learning support & $\begin{array}{l}\text { feel their university is providing the support the } \\
\text { needs for their studies. }\end{array}$ \\
\hline \multirow[t]{2}{*}{$\begin{array}{l}\text { Institutional } \\
\text { attachment }\end{array}$} & $\begin{array}{l}\text { Commitment to } \\
\text { the institution }\end{array}$ & $\begin{array}{l}\text { feel loyalty to their specific university and their } \\
\text { intent to graduate from it. }\end{array}$ \\
\hline & $\begin{array}{l}\text { Emotional } \\
\text { attachment }\end{array}$ & $\begin{array}{l}\text { feel emotional attachment and connection to their } \\
\text { specific university. }\end{array}$ \\
\hline Satisfaction & Utility & $\begin{array}{l}\text { recognize the future value, usability, and utility } \\
\text { of their studies and their results. }\end{array}$ \\
\hline $\begin{array}{c}\text { External } \\
\text { environment }\end{array}$ & $\begin{array}{l}\text { External commit- } \\
\text { ments }\end{array}$ & $\begin{array}{l}\text { feel a personal bond, external to the study envi- } \\
\text { ronment (family, community, etc.) }\end{array}$ \\
\hline
\end{tabular}


After the data collection using self-evaluated statements, the system computes and visualizes the meaning of the knowledge input collected from the respondents. Such a fuzzy logic-based system reminds an expert's task of evaluating and reasoning based on linguistic information.

\section{Research Design and Analysis}

In this research, we compared the self-evaluation results obtained using the previously described application from a private business school to the results of public universities. The case study was carried out at the HULT International Business School, in London, UK. 110 students who attended a course on Creating Problem Solving in two semesters were asked to participate in the research. In the end, 40 undergraduate students $(36.4 \%$ of the participants) completed the research instrument. The mean age of the respondents was 21 years of age. Sixty-five (65\%) percent of the respondents were male, and 35\% female. In all, the respondents had 24 different nationalities. Overall, we have studied student engagement in 14 different universities with over 1100 students over the past 5 years. With the current improved version (v.2.0) of the instrument, we have had over 400 evaluation results. In this research, the business school students were compared to overall research data gathered from public universities with the instrument $(\mathrm{n}=353)$.

The comparison of the groups was made using an effect size described by Cohen's d-values. Using the effect size in the analysis helps to easily identify the areas or the specific items where the benchmarked university is doing well compared to others, as well as to find out the areas or items for improvement. The effect size tells the relative magnitude of the difference between the two groups. It indicates the relative importance of the difference in scores between a treatment and a comparison group in an easy to understand way. By using the effect size, it was also possible to compare the obtained values to known benchmark values [21]. By using this method we can compare their differences based on respondents' evaluations. In the analysis, HULT was regarded as the treatment group and the combination of the other institutions (public universities) as the comparison (control) group. This way if the results are positive, HULT got higher scores. Effect sizes can also be negative if the treatment group performs on a lower level than the control group. However, the negative sign can also be an indication of scale direction instead of a perceived lack of performance. By using the effect size, it is possible to compare the difference to known benchmark values established by Cohen [21]. Cohen [21] describes d-values of 0.20 as small, 0.50 as medium (moderate), and 0.80 as large. Cohen states that a moderate effect size is large enough to be "visible to the naked eye". The calculation of Cohen's d is straightforward. It can be calculated by dividing the difference between the two group means by their pooled standard deviation. By using effect size, items that have practical significance can be identified quickly which helps in the interpretation of the results. 


\section{Results}

According to the results, the benchmarked institution scored higher mean values in 95 percent of statements than the mean results of all the cases conducted with the instrument. Five of the statements scored higher than the d-value of 0.8 , which Cohen describes a large effect size. Forty of the statements scored between 0.5 and 0.8 , which according to Cohen, can be viewed as a moderate magnitude of difference between the groups. Table 2 presents all the statements where the d-value was higher than 0.6 . The cutoff value of 0.6 was chosen to see the statements that have a relatively high effect size. Also, the only statement where HULT scored moderately high negative value is presented.

Table 2. Statements and d-values distinguishing HULT

\begin{tabular}{|l|c|}
\hline \multicolumn{1}{|c|}{ Statement } & d-value \\
\hline I am committed to achieving my study related goals & 1.05 \\
\hline Sometimes I think it is not important for me to get a new degree (R) & 0.91 \\
\hline I feel competent regarding the courses I am taking & 0.82 \\
\hline $\begin{array}{l}\text { My teachers and professors are accessible and give me support and help } \\
\text { when I need it }\end{array}$ & 0.81 \\
\hline I have access to study counseling I need & 0.80 \\
\hline $\begin{array}{l}\text { Provided materials and informational resources support the effective func- } \\
\text { tioning }\end{array}$ & 0.75 \\
\hline The courses and their activities are very interesting and rewarding & 0.72 \\
\hline Teaching styles and environment promote creativity and innovation & 0.70 \\
\hline $\begin{array}{l}\text { I feel no obligation to remain and study with this particular university until } \\
\text { I graduate (R) }\end{array}$ & 0.70 \\
\hline My university provides me the things I am/was looking for & 0.69 \\
\hline Teaching methods in this university are innovative & 0.68 \\
\hline $\begin{array}{l}\text { Performing on individual courses motivates me to continue my studies and } \\
\text { to obtain the degree }\end{array}$ & 0.67 \\
\hline I feel unsure about my abilities to pass the tests I need to take (R) & 0.67 \\
\hline Students can challenge or appeal to decisions concerning them & 0.67 \\
\hline The educators support my autonomy & 0.67 \\
\hline I get full credit and recognition for the work I do & 0.65 \\
\hline The style of teaching keeps me interested & 0.63 \\
\hline My goal is to complete all the courses needed to obtain this degree & 0.63 \\
\hline The educators regard me as a valued individual & 0.63 \\
\hline Lack of alternative places to study keeps me in this university (R) & 0.63 \\
\hline Teachers/professors motivate the students to learn and reach their goals & 0.62 \\
\hline The educators are good at communicating with the students & 0.61 \\
\hline It was my personal choice to study in this degree programme & 0.60 \\
\hline $\begin{array}{l}\text { My studies have a negative effect on my personal or family life e.g. finan- } \\
\text { cial or time pressures }\end{array}$ & -0.48 \\
\hline
\end{tabular}


These results indicated that the assessed private university scored better in the evaluation than the other public universities assessed. For example, the value $d=0.5$ means that the assessed HULT students scored $50 \%$ a standard deviation more than all the assessed students from the public universities.

\section{Discussion}

The main goal of the assessment presented in this paper was to find out if there were differences between private and public universities regarding the students' selfreported engagement and motivation. The analysis was done on the statement level to see the specific item where the major differences existed. This type of analysis can be used to "benchmark" the institution and to compare it to others. Benchmarking also provides an interesting reference point for implementing and managing change. Comparisons to other groups and subsequent analysis can uncover good and useful practices utilized by other institutions. This methodology with its methods to give university management new insight and information that can help them in their leadership and planning activities. By using the information gathered directly from the students, the management is more inclined to make effective developments plans because they can be based on such bottom-up information. These activities can, for example, help to advance the retention and satisfaction of the students. We have shown with our research that the respondents feel this way much more highly than the long-term average from multiple cases in different conventional universities. The test results seem to support the belief that students feel comfortable and that their university is interested in their motivation and learning. Based on the results, the students feel their private university invests effectively in their engagement compared to the results from the reference universities.

\section{References}

1. Kuh, G. D. What student affairs professionals need to know about student engagement. Journal of College Student Development, 50(6), 683-706. (2009).

2. Burch, G. F., Heller, N. A., Burch, J. J., Freed, R., \& Steed, S. A. Student Engagement: Developing a Conceptual Framework and Survey Instrument. Journal of Education for Business, 90(4), 224-229. (2015).

3. Schaufeli, W. B., Martínez, I. M., Pinto, A. M., Salanova, M., \& Barker, A. B. Burnout and engagement in university students a cross-national study. Journal of Cross-Cultural Psychology, 33(5), 464-481. (2002).

4. Harper, S.R. and Quaye, S.J.: Beyond sameness, with engagement and outcomes for all. In: Harper, S.R.. Quaye, S.J. Student engagement in higher education. New York and London: Routledge, 1-15. (2009).

5. Astin, A. Student Involvement: A Developmental Theory for Higher Education. Journal of College Student Personnel, 25(4), 297-308. (1984).

6. Kuh, G. D. Assessing What Really Matters to Student Learning Inside The National Survey of Student Engagement. Change: The Magazine of Higher Learning, 33(3), 10-17. (2001). 
7. Appleton, J. J., Christenson, S. L., Kim, D., \& Reschly, A. L. Measuring cognitive and psychological engagement: Validation of the Student Engagement Instrument. Journal of School Psychology, 44(5), 427-445. (2006).

8. Stoeva, P., \& Pitas, J. Military Students Motivation : Comparative Analysis. In Economics And Management (pp. 40-48). Brno: University Of Defence/Czech Republic. (2018).

9. Lotkowski, V.A., Robbins, S.B., and Noeth, R.J.: The Role of Academic and Non- Academic Factors in Improving College Retention. ACT Policy Report. American Col- lege Testing ACT Inc. ERIC. (2004)

10. Hart, S. R., Stewart, K. \& Jimerson, S. R. The Student Engagement in Schools Questionnaire (SESQ) and the Teacher Engagement Report Form-New (TERF-N): examining the preliminary evidence. Contemporary School Psychology, 15, 67-79. ERIC. (2011).

11. Tinto, V.: Promoting student retention through classroom practice. Enhancing Student Retention: Using International Policy and Practice, an international conference sponsored by the European Access Network and the Institute for Access Studies at Staffordshire University. Amsterdam, 5-7. (2003)

12. Kantola, J.: Ontology-based resource management. Human Factors and Ergonomics in Manufacturing \& Service Industries, 19(6), 515-527. Wiley Online Library. (2009).

13. Kantola, J.: Organizational Resource Management: Theories, Methodologies, and Applications. CRC Press. (2015).

14. Kantola, J., Karwowski, W. and Vanharanta, H.: Managing managerial mosaic: the Evolute methodology. Electronic Globalized Business and Sustainable Development Through IT Management: Strategies and Perspectives, 77-89. (2011).

15. Tinto, V. Dropout from higher education: A theoretical synthesis of recent research, Review of Educational Research. 89-125. (1975)

16. Tinto, V. Leaving College: Rethinking the Causes and Cures of Student Attrition, University of Chicago Press. (1987).

17. Bean, J. P.: Dropouts and Turnover: The Synthesis and Test of a Causal Model of Student Attrition, ERIC. (1979).

18. Bean, J. P.: Student attrition, intentions, and confidence: Interaction effects in a path model, Research in Higher Education. 17, 291-320. (1982).

19. Gruber, T. R. A translation approach to portable ontology specifications. Knowledge Acquisition, 5(2), 199-220. Elsevier. (1993).

20. Arvidsson, F. \& Flycht-Eriksson, A. Ontologies I. Retrieved Jan 9, 2014 from http://www.ida.liu. se/janma/SemWeb/Slides/ontologies1.pdf. (2008).

21. Cohen, J. Statistical power analysis for the behavioral sciences. Hillsdale, NJ: Erlbaum. (1988). 